\title{
Study on Chinese and U.S. Energy Efficiency Regulations and Standards for Efficient Lighting Products
}

\author{
Qing Ding*, Xiuying Liang, Yuejin Zhao, Ren Liu, Pengcheng Li, Meng Liu, Ling Lin \\ Resource and Environment Branch, China National Institute of Standardization, No 4, Zhichun Street, Haidian District, Beijing, China
}

\begin{abstract}
We have analyzed Chinese and U.S. Energy efficiency policies, regulations and standards for LED and other efficient lighting products. The similarities and differences of the lighting products between the two countries in the energy efficiency policies and technical indexes were contrasted and analyzed. Accordingly, we have put forward the recommendations for improving China's efficient lighting standards system as well as establishing and implementing the effective labelling and certification programs of efficient lighting products.
\end{abstract}

\section{Background}

Under the background of global energy shortage currently, energy saving and emission reduction and green development have become the common concerns of countries in the world. According to statistics, global lighting accounts for about $20 \%$ of total power consumption. Lighting in China accounts for about $14 \%$ of total power consumption. Therefore, lighting has always been the key area of energy conversation in China and the world. LED lighting product as a new energy-saving green lighting product is featured with low energy consumption, high controllability, rich color, long service life and so on. Its development, application and promotion have been expanded constantly in recent years.

China is the biggest producer, consumer and exporter of efficient lighting products in the world. U.S. is in the front ranks of the world in the LED chip technology, which leads the development of the global LED lighting industry. Meanwhile, it is one of the most important exporters of China's efficient lighting products. Therefore, it is of great significance for promoting the improvement and upgrading of China's efficient lighting industry to process the Chinese and U.S. energy efficiency regulations and standards for efficient lighting products, contrast and analyze the performance indexes and test method, make recommendations on the scientific, reasonable and targeted policy, improve the standard system, and propose the revised suggestions for the key standard systems.

\section{Energy efficiency standards and regulations for efficient lighting products}

\subsection{China}

\subsubsection{Energy saving certification}

The certification of energy saving products means that the certification authorities of energy saving products issue the authentication certificates and the energy saving labels after the confirmation based on the certification standards and technical requirements according to the international general regulations and procedures, which is regarded by the governments of many countries in the world as the important mean and measure to implement the energy saving management, improve the efficiency of energy utilization, regulate the energy-using products market and promote the progress in energy saving technology. In order to ensure the energy-saving quality of products, China has implemented the voluntary energy saving certification program since 1998 .

Energy-saving product certification is a voluntary certification program for ensuring energy saving quality of products. For products with energy-saving product authentication certification, certification marks can be used in energy-using products or their packages.

China has implemented energy saving certification for LED lighting products since 2011. Presently, energy saving certification covers the following products: LED road/tunnel lighting products, LED downlights, LED flat panel luminaires, directional integrated LED lamps, non-directional self-ballasted LED lamps for general lighting services and double-capped retrofit LED lamps. It is of great significance for regulating the market of LED lighting products in China, promoting the application and popularization of LED lighting products and enhancing energy saving awareness of the whole society ${ }^{[1]}$. 


\subsubsection{Government procurement of efficient lighting products}

The government procurement program of energy saving products is a compulsory promotion program for energy saving products which has been implemented in China since 2007. This program clearly specifies that the government is enforced to purchase some products whose energy-saving effects and performance have met the requirements in order to promote energy saving and protect the environment.

China has implemented the government procurement program for efficient lighting products since January 2013, including 3 types of LED lighting products, i.e. LED road/tunnel lighting products, LED downlights and directional integrated LED lamps, into the government procurement list of energy-saving products and requiring government bodies at all levels to give priority to procurement of efficient lighting products, so as to promote energy saving and emission reduction through the exemplary role of government bodies. Beijing, Guangdong, Shaanxi and other places have been active in carrying out promotion and public bidding projects for efficient LED lighting products, and promoting the application of efficient LED lighting products in public institutions including schools, hospitals and large public buildings such as transportation and cultural venues.

\subsubsection{Energy efficiency Top-Runner Program}

Energy efficiency "Top Runner" Program refers to the product, enterprise or unit with the highest efficiency of energy utilization within the range of comparable products, enterprises or units of the same type. Establish and carry out the energy efficiency "Top Runner" Program for energy-using products, release the catalog of end energy-using products with the highest efficiency of energy utilization and energy efficiency indexes on a regular basis, facilitate the establishment of a long-effect mechanism which promotes the energy efficiency improvement of end energy-using products and promote energy saving and emission reduction through benchmark establishment, policy incentives and standard improvement.

In December 2017, the National Development and Reform Commission released the Implementation Rules for Energy Efficiency "Top Runner" Program of lighting products, setting up the energy efficiency "Top Runner" Program for LED road and tunnel lighting products ${ }^{[2]}$. Products with the energy efficiency "Top Runner" label will be included in the government procurement list of energy-saving products and purchased preferentially. Energy efficiency "Top Runner" products will be used preferentially in fixed assets investment projects and energy saving transformation projects with central government investment in capital construction and government funds support.

\subsection{U.S}

United States has always been leading the world on the establishment of standards and specifications for LED. United States Department of Energy (DOE) has carried out the broad cooperation with many organizations, such as IEC, CIE, IESIA, National Institute of Standards and Technology (NIST), Canadian Standards Association (CSA) and UL, and formed a series of relatively improved standards and specifications for the safety, electromagnetic compatibility, performance, testing methods and requirements.

Based on the above standards, the performance, energy efficiency and other general requirements for the residential lighting products, outdoor and indoor commercial lamps have been specified under the Energy Star and DLC (The Design Lights Consortium) Certification Programs of great influence in the world.

\subsubsection{Energy Star Certification Program}

Energy Star is a voluntary certification program jointly carried out by DOE and the United States Environmental Protection Agency (EPA) to better protect the living environment and save energy, which was firstly popularized in the computer products by EPA in 1992. Although it is not a compulsory certification, Energy Star and its label have become the most authoritative energy efficiency certification mechanism for the electromechanical products in the world.

In July, 2007, DOE presented the draft of the Five-Year Plan for Supporting commercialization of solid-state lighting, which included the Energy Star standards for solid-state lighting lamps, the development of other related standards, evaluation report and design competition of commercial luminous diodes, $\operatorname{etc}^{[3]}$. On December 3, 2009, DOE officially released the Energy Star standards for LED lamps, and put it into effect on August 31, 2010. The release of this standard shows that there is at least a standard for the energy saving in the lighting industry to be followed. Meanwhile, the safety standard will be completed in the future, which is helpful to accelerate the growth of the lighting industry.

Lighting products under U.S. Energy Star Certification Program can be divided into the LED light sources and the traditional light sources according to the lighting principles of difference lighting sources. The LED lighting products include the LED bulbs and LED lamps, and the lighting products with traditional light sources include the incandescent light bulbs, HID lamps, fluorescent lamps and compact fluorescent bulbs. These specifications were made by EPA and DOE respectively, but due to the inconsistent requirements and less products covered, they have long been inadequate to meet the needs of the industry. Therefore, in the Energy Star Certification Program, the standards for the lighting products have been integrated. The current technical specifications for lighting products include three parts: lamps, one-piece bulbs and decorative light strings.

Since 2011, Energy Star has adopted the third-party certification mode rather than self-declaration mode. The experimental data released by the laboratories accredited by DOE shall be certified by the institution 
(EPA-recognized CB) accredited by it. The basic certification steps can be summarized as: joining the program - product testing - certification - obtaining the certificate - test confirmation - accepting the challenges from other members in the program. In the Energy Star Certification Program, all manufacturers are required to be checked and authorized by American National Voluntary Laboratory Accreditation Program (NVLAP), and the test results must be accepted by DOE and EPA and issued by the approved laboratories. The tested products must pass the safety test, and relevant test reports and life reports must be provided. ENERGY STAR $®$ Labeled products must be certified by the third party in the laboratories accredited by EPA and checked randomly and regularly. If the product is not qualified, the Energy Star label will be cancelled immediately, and the relevant manufacturers shall compensate the consumers for corresponding losses.

\subsubsection{DLC Certification Program}

DLC is a voluntary energy efficiency certification program initiated by Northeast Energy Efficiency Partnerships (NEEP), which takes the leading position in the certification of energy-efficient lighting quality and performance. DLC has gradually become an essential certification standard for LED lamps and it can make the end energy-using customers obtain the abundant government subsidies. DLC is initiated for the purpose of promoting the popularization of high-quality and energy-efficient lighting design in all commercial lighting fields and the generalization of high-performance LED lamps in the product list of DLC that are used in the various regions of the U.S. but are not covered in the Energy Star Standard. The products involved are mainly the outdoor commercial and industrial LED lamps and LED modulator tubes. The latest version for the current technical requirements of DLC is the V4.3 that has taken effect since March 26, 2018, covering the lighting products like outdoor, industrial building and indoor commercial lamps, road lamps, outdoor wall lamps, garage lamps, landscape floodlights, mining lamps, staircase lamps, cabinet lamps and indoor commercial lighting products. Its main performance requirements for the products include: total luminous flux, lighting efficacy, color temperature, color rendering index (CRI), lumen maintenance, power factor, harmonic distortion, etc.
DLC Certification Program will regularly update its qualified product list (QPL) every year. The updating process is as follows: the manufacturer or organization applies to DLC for product supplement - form a revised draft of list - the technical committee checks the draft ask all interested parties for advices - the technical committee handles the comments and forms a final draft for approval. In the DLC Certification, the products must be tested by a third-party laboratory accredited by NVLAP and the test reports shall be provided. The test reports and data shall become valid upon the approval by the National Voluntary Laboratory Accreditation Program (NVLAP).

\section{Energy efficiency index of lighting products}

\subsection{United States}

\subsubsection{Energy Star}

The original intentions to initiate the Energy Star Certification Program are to better protect the living environment and save energy. Thus, the energy efficiency index is one of the most important indexes in the technical requirements of the program. For the non-decorative bulbs, Energy Star Certification Program has higher requirements on the lighting efficacy of the bulbs with low CRI, lower requirements on that of the bulbs with high CRI. Because the blue LED chips in the most commercialized LED lighting products are painted with the yellow phosphor which is excited by the blue light, and the blue light sent out by the chips and the yellow light sent out by the phosphor interact with each other to form the white light, the color rendering is usually not high with the lack of red spectrum. At present, many manufacturers make up for the shortage of the red spectrum of LED by adding the red phosphor to adjust the CRI of white light. Besides, the optical conversion efficiency is low when the red phosphor is excited, which will reduce the overall lighting effect of LED invisibly. Meanwhile, we can clearly see the encouragement and protection of the Energy Star Certification Program for the high-quality lighting products with high CRI. The requirements for the energy efficiency indexes of bulbs and lamps in the Energy Star Certification Program are shown in Table 1 and Table $2^{[4][5]}$.

Table 1. Energy efficiency indexes of lamps in Energy Star Certification Program

\begin{tabular}{|c|c|c|}
\hline \multirow{2}{*}{ Lamp Types } & \multicolumn{2}{|l|}{$\begin{array}{l}\text { Minimum Luminous } \\
\text { Efficacy (Im/W) }\end{array}$} \\
\cline { 2 - 3 } & CRI $\geq \mathbf{9 0}$ & $\mathbf{C R I < 9 0}$ \\
\hline Omnidirectional & 70 & 80 \\
\hline Directional & 61 & 70 \\
\hline Decorative & \multicolumn{2}{|c|}{65} \\
\hline
\end{tabular}


Table 2. Energy efficiency index of luminaires in Energy Star Certification Program

\begin{tabular}{|c|c|c|c|}
\hline \multicolumn{3}{|c|}{ Luminaire Types } & $\begin{array}{l}\text { Minimum Luminous Efficacy } \\
\qquad(\operatorname{lm} / \mathbf{W})\end{array}$ \\
\hline \multirow{5}{*}{$\begin{array}{l}\text { omnidirectional } \\
\text { luminaires }\end{array}$} & & CFL & \multirow{2}{*}{$65 \mathrm{~lm} / \mathrm{W}$} \\
\hline & \multicolumn{2}{|c|}{ circline fluorescent } & \\
\hline & \multicolumn{2}{|c|}{ LED light engine } & $65 \mathrm{~lm} / \mathrm{W}$ \\
\hline & \multicolumn{2}{|c|}{ surface mounted retrofit for diffused wall sconces } & $65 \mathrm{~lm} / \mathrm{W}$ \\
\hline & \multicolumn{2}{|c|}{$\begin{array}{l}\text { surface mounted retrofits for diffused ceiling mounted } \\
\text { lights }\end{array}$} & $65 \mathrm{~lm} / \mathrm{W}$ \\
\hline \multirow{11}{*}{$\begin{array}{l}\text { directional } \\
\text { luminaires }\end{array}$} & \multicolumn{2}{|c|}{ cove or under cabinet mount } & $50 \mathrm{~lm} / \mathrm{W}$ \\
\hline & \multirow{3}{*}{ downlights } & recessed & \multirow{3}{*}{$55 \mathrm{~lm} / \mathrm{W}$} \\
\hline & & surface & \\
\hline & & pendant & \\
\hline & \multicolumn{2}{|c|}{ downlights retrofits } & $60 \mathrm{~lm} / \mathrm{W}$ \\
\hline & \multirow{3}{*}{ accent lights } & track light luminaires & \multirow{3}{*}{$55 \mathrm{~lm} / \mathrm{W}$} \\
\hline & & & \\
\hline & & line voltage track heads & \\
\hline & \multicolumn{2}{|c|}{$\begin{array}{l}\text { outdoor, wall-porch-pendant, post-mounted and } \\
\text { security luminaires }\end{array}$} & $60 \mathrm{~lm} / \mathrm{W}$ \\
\hline & \multicolumn{2}{|c|}{ portable desk task } & $50 \mathrm{~lm} / \mathrm{W}$ \\
\hline & \multicolumn{2}{|c|}{ inseparable LED luminaires } & $70 \mathrm{~lm} / \mathrm{W}$ \\
\hline
\end{tabular}

well as standard requirements of lamps. Specific index

\subsubsection{DLC} has been shown in Table 3(a)(b) ${ }^{[6]}$.

DLC Certification Program specifies standard and premium requirements of luminaires and retrofit kits as

Table3(a). Energy efficiency index of luminaires and retrofit kit in DLC Certification Program

\begin{tabular}{|c|c|c|c|c|}
\hline \multirow{2}{*}{ Types } & \multirow{2}{*}{ Category } & \multirow{2}{*}{ General Application } & \multicolumn{2}{|c|}{ Minimum Luminous Efficacy $(\mathrm{Im} / \mathrm{W})$} \\
\hline & & & DLC Standard & DLC Premium \\
\hline & \multirow{4}{*}{ outdoor } & outdoor-low output & 90 & 110 \\
\hline & & output-mid output & 95 & 115 \\
\hline & & output-high output & 100 & 120 \\
\hline & & output-very high output & 100 & 120 \\
\hline & \multirow{5}{*}{ indoor } & interior directional & 65 & 90 \\
\hline & & case lighting & 80 & 125 \\
\hline & & troffer & 100 & 125 \\
\hline & & linear ambient & 105 & 130 \\
\hline & & high bay & 105 & 130 \\
\hline \multirow{7}{*}{ retrofit kit } & \multirow{4}{*}{$\begin{array}{l}\text { outdoor } \\
\text { retrofit kit }\end{array}$} & outdoor-low output & 90 & 110 \\
\hline & & outdoor-mid output & 95 & 115 \\
\hline & & outdoor-high output & 100 & 120 \\
\hline & & output-very high output & 100 & 120 \\
\hline & \multirow{3}{*}{$\begin{array}{l}\text { indoor retrofit } \\
\text { kit }\end{array}$} & troffer & 125 & 125 \\
\hline & & linear ambient & 130 & 130 \\
\hline & & high-bay & 130 & 130 \\
\hline
\end{tabular}


Table3(b). Energy efficiency index of lamps in DLC Certification Program

\begin{tabular}{|c|c|c|c|c|}
\hline Types & Category & General Applic & & $\begin{array}{c}\text { DLC Standard } \\
\text { Luminous Efficacy }\end{array}$ \\
\hline \multirow{25}{*}{ lamps } & \multirow{14}{*}{$\begin{array}{l}\text { linear } \\
\text { replacement } \\
\text { lamps }\end{array}$} & \multirow{2}{*}{$\begin{array}{l}\text { T8 four-foot linear } \\
\text { replacement lamps }\end{array}$} & in luminaire & 100 \\
\hline & & & bare lamp & 110 \\
\hline & & \multirow{2}{*}{$\begin{array}{l}\mathrm{T} 5 \text { four-foot linear } \\
\text { replacement lamps }\end{array}$} & in luminaire & 100 \\
\hline & & & bare lamp & 110 \\
\hline & & \multirow{2}{*}{$\begin{array}{l}\text { T5HO four-foot linear } \\
\text { replacement lamps }\end{array}$} & in luminaire & 105 \\
\hline & & & bare lamp & 110 \\
\hline & & \multirow{2}{*}{$\begin{array}{l}\text { T8 two-foot linear } \\
\text { replacement lamps }\end{array}$} & in luminaire & 100 \\
\hline & & & bare lamp & 110 \\
\hline & & \multirow{2}{*}{ U-bend replacement lamps } & in luminaire & 100 \\
\hline & & & bare lamp & 110 \\
\hline & & \multirow{2}{*}{$\begin{array}{l}\text { T8 three-foot linear } \\
\text { replacement lamps }\end{array}$} & in luminaire & 100 \\
\hline & & & bare lamp & 110 \\
\hline & & \multirow{2}{*}{$\begin{array}{l}\text { T8 eight-foot linear } \\
\text { replacement lamps }\end{array}$} & in luminaire & 100 \\
\hline & & & bare lamp & 110 \\
\hline & \multirow{5}{*}{$\begin{array}{c}\text { Mogul } \\
\text { screw-base(E } \\
39) \\
\text { replacements } \\
\text { for HID lamps }\end{array}$} & outdoor-low output & \multirow{5}{*}{ in luminaire } & 90 \\
\hline & & outdoor-mid output & & 90 \\
\hline & & outdoor-high output & & 95 \\
\hline & & *outdoor-very high output & & 95 \\
\hline & & high-bay & & 100 \\
\hline & \multirow{6}{*}{$\begin{array}{l}\text { four pin-base } \\
\text { replacement } \\
\text { lamps for } \\
\text { CFLs }\end{array}$} & \multirow{2}{*}{ vertically-mounted lamps } & in luminaire & 65 \\
\hline & & & bare lamp & 75 \\
\hline & & \multirow{2}{*}{ horizontally-mounted lamps } & in luminaire & 65 \\
\hline & & & bare lamp & 75 \\
\hline & & \multirow{2}{*}{$2 \mathrm{G} 11$ base replacement lamps } & in luminaire & 100 \\
\hline & & & bare lamp & 110 \\
\hline
\end{tabular}

\subsection{China}

China has formulated 13 national energy efficiency standards for lighting equipment successively since the development of the first energy efficiency standard concerning lighting equipment in 1999. GB30255-2013 Minimum Allowable Values of Energy Efficiency and Energy Efficiency Grades of Non-directional Self-ballasted LED Lamps is the first national energy efficiency standard for LED lighting products issued and implemented by China. Currently, two national energy efficiency standards concerning LED luminaires for road / tunnel lighting and LED products for indoor lighting have been developed and reported to SAC for approval. So far, national energy efficiency standards for LED lighting products in China have covered the following products: LED luminaires for road / tunnel lighting, LED downlights, directional integrated LED lamps and non-directional self-ballasted LED lamps. Additionally, industrial, local and association energy efficiency standards have been formulated for 5 kinds of lighting products including LED road and tunnel lamps and exit marking LED lamps.

In China, energy efficiency of LED lighting products has 3 grades. Grade 1 means the highest energy efficiency, followed by Grade 2 and Grade 3 in turn. Phase out products with low energy efficiency by Grade 3 index, thus to promote energy efficiency improvement for low-efficiency products; expand the market share of energy-saving products by Grade 2 index; reinforce the leading role of ultra-efficient products by Grade 1 index, so as to drive further energy efficiency improvement of high-efficiency products. With the timely revision of 
energy efficiency standards, a virtuous cycle rises of energy efficiency index continues to improve the energy efficiency of LED lighting products in China.

The energy efficiency index system for LED lighting products mainly includes luminous efficiency, correlated color temperature, color rendering index, lumen maintenance and other technical indexes. Table 4 shows main technical indexes in energy efficiency standards for LED lighting products.

Table 4 Energy efficiency index of LED lighting products

\begin{tabular}{|c|c|c|c|c|c|c|}
\hline \multirow[b]{2}{*}{ Types } & \multirow{2}{*}{\multicolumn{2}{|c|}{ Catogory }} & \multirow{2}{*}{$\begin{array}{l}\text { Rated correlated } \\
\text { color temperature } \\
(\mathrm{CCT}) \\
\mathrm{K} \\
\end{array}$} & \multicolumn{3}{|c|}{ luminous efficacy } \\
\hline & & & & Grade & Grade & Grade \\
\hline \multirow{4}{*}{ LED downlights } & \multirow{4}{*}{$\begin{array}{c}\text { rated power } \\
\text { W }\end{array}$} & \multirow{2}{*}{$\leq 5$} & $\mathrm{CCT}<3500$ & 95 & 80 & 60 \\
\hline & & & $\mathrm{CCT} \geq 3500$ & 100 & 85 & 65 \\
\hline & & \multirow{2}{*}{$>5$} & $\mathrm{CCT}<3500$ & 105 & 90 & 70 \\
\hline & & & $\mathrm{CCT} \geq 3500$ & 110 & 95 & 75 \\
\hline \multirow{4}{*}{$\begin{array}{c}\text { Directional } \\
\text { intergrated LED } \\
\text { lamps }\end{array}$} & \multirow{4}{*}{$\begin{array}{l}\text { lamp holder } \\
\text { type }\end{array}$} & \multirow{2}{*}{ PAR16/PAR20 } & $\mathrm{CCT}<3500$ & 95 & 80 & 65 \\
\hline & & & $\mathrm{CCT} \geq 3500$ & 100 & 85 & 70 \\
\hline & & \multirow{2}{*}{ PAR30/PAR38 } & $\mathrm{CCT}<3500$ & 100 & 85 & 70 \\
\hline & & & $\mathrm{CCT} \geq 3500$ & 105 & 90 & 75 \\
\hline \multirow{4}{*}{$\begin{array}{l}\text { non-directional } \\
\text { self-ballast LED } \\
\text { lamps }\end{array}$} & \multirow{4}{*}{$\begin{array}{l}\text { Light } \\
\text { distribution } \\
\text { type }\end{array}$} & \multirow{2}{*}{$\begin{array}{c}\text { full light } \\
\text { distribution }\end{array}$} & $\mathrm{CCT}<3500$ & 105 & 85 & 60 \\
\hline & & & $\mathrm{CCT} \geq 3500$ & 115 & 95 & 65 \\
\hline & & \multirow{2}{*}{$\begin{array}{c}\text { half light } \\
\text { distribution/Quasi- } \\
\text { full light English }\end{array}$} & $\mathrm{CCT}<3500$ & 110 & 90 & 70 \\
\hline & & & $\mathrm{CCT} \geq 3500$ & 120 & 100 & 75 \\
\hline \multirow{6}{*}{$\begin{array}{l}\text { luminaires for } \\
\text { road and tunnel } \\
\text { lighting }\end{array}$} & \multirow{6}{*}{$\begin{array}{c}\text { rated power } \\
\text { W }\end{array}$} & \multirow{3}{*}{$\leq 60$} & $\mathrm{CCT}<3500$ & 125 & 115 & 95 \\
\hline & & & $3500 \leq \mathrm{CCT} \leq 5000$ & 130 & 120 & 100 \\
\hline & & & $\mathrm{CCT}>5000$ & -- & -- & 125 \\
\hline & & \multirow{3}{*}{$>60$} & $\mathrm{CCT}<3500$ & 130 & 120 & 100 \\
\hline & & & $3500 \leq \mathrm{CCT} \leq 5000$ & 135 & 125 & 105 \\
\hline & & & $\mathrm{CCT}>5000$ & -- & -- & 130 \\
\hline
\end{tabular}

\section{Enlightenment to implementation of regulations and standards for lighting products in China}

\subsection{Integration and timely revising of the standards for the like products}

In Energy Star and DLC Certification Programs, the like lighting products are highly integrated and compacted, of which the technical specifications for the bulbs and lamps in the Energy Star Certification Program cover the residential lighting products, such as lamps, one-piece bulbs and decorative light strings (including both of the traditional and LED light sources), and the DLC covers the outdoor and industrial LED lighting products. Meanwhile, the technical specifications in the Energy Star and DLC Certification Programs are updated quickly, of which the technical specifications in DLC are updated for 2 to 3 times within a year. Thus, it can adapt to the market changes and lead the technological progress to a great extent.

In combination with the requirements of the Integration and Simplification of Compulsory Standards in China, it is recommended to classify and integrate the standards for the lighting products according to the lighting principles, purposes and use of lighting products. For example, in the national standards Minimum allowable values of energy efficiency and energy efficiency grades of LED products for road/tunnel lighting and Minimum allowable values of energy efficiency and energy efficiency grades of LED products for indoor lighting just submitted for approval, the outdoor and indoor LED lighting products are integrated separately. Meanwhile, in view of the fast technical development of LED lighting products, it is recommended to establish a rapid standard revision mechanism to track the changes of product indexes dynamically and shorten the revision cycles of standards.

\subsection{Overall evaluation of the efficient and high-quality green lighting products}

The implementation of the Energy Star and DLC Certification Programs shows that, in the face of the increasingly competitive European American markets, in addition to the compulsory certification test, stroboscopic verification, spectrum measurement and color consistency and other additional performance of the LED lighting product, often makes it stand out among the numerous like products, because the comfort, health and light quality, of the lighting product has be more valued by the consumers.

At present, the luminous efficacy of LED lighting products is very high compared to that of the traditional light sources. Although the luminous efficacy can be improved continuously, it is no longer the only focal point. The improvement of the light quality and the health, ecology and safety of the light environment are more attractive. People pay more attention to the healthy problems caused by the light environment, such as stroboflash and blue light. Therefore, in accordance with 
the Opinion on Developing a Unified Standard, Certification and Labeling Program of Green Products (GBF [2016] No.86), it is recommended to establish a comprehensive index evaluation system for the LED lighting products, covering the energy, resources, environment and quality attributes of the products, and study and establish the technical standards for the efficient and high-quality green lighting products.

\section{Acknowledgment}

Supported by National key research and development plan Program "Research on the standard system and standards of energy consumption and intensity double control of building material and coal industry."(2016YFF0201501)

\section{References}

1. Zheng Xuesheng, Chen Song. Analysis on performance of China's first batch of LED lighting products with energy saving certificates.[M] 2013(6)24-3(in Chinese)

2. Notice about print and distribute "top runner" program implementation regulations and search of 5 catalog products including washing machine, lighting products, etc(FGHZ[2017]No 2071) (in Chinese)

3. Wan Yong et al., Domestic and Foreign Industry Standards for LED Lighting Products,

High-Technology and Industrialization [M] 2018 (1) 176 (in Chinese)

4. Energy Star Program Requirements for Lamps(Light Bulbs) Partner Commitments V2.1

5. Energy Star Program Requirements for Luminaires Partner Commitments V2.1

6. SSL Technical Requirements V4.3 